ARAŞTIRMA MAKALESI

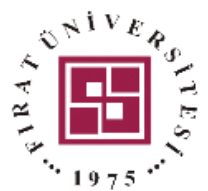

Frrat Üniversitesi Sosyal Bilimler Dergisi

The Journal of International Social Sciences

Cilt: 30, Say1: 2, Sayfa: 519-534, TEMMUZ - 2020

Makale Gönderme Tarihi: 25.02.2020 Kabul Tarihi: 22.06.2020

\title{
XVI. YÜZYILDA OSMANLI DEVLETINDE KARABORSACILIK ve KAÇAKÇILIK
}

\author{
Black Marketing and Smuggling in the Sixteenth Century in the Ottoman Empire
}

\section{Savaş YILMAZ*}

$\ddot{O} \mathbf{Z}$

Osmanlı Devleti’nde karaborsacılık ile kaçakçılık suçları XVI. yüzyılın ilk yarısında fazla görülmemişken, bu suçların, bu yüzyılın ikinci yarısında etkili olmasında; Osmanlı-Avusturya Macaristan ve Osmanl-İ́ran savaşları, Kanûn-1 kadimin bozulması ile Celali isyanlarına bağlı olarak üretim ile tüketim arasındaki dengenin kırsaldan şehir merkezlerine yapılan göçlerle bozulması gibi sebepler gösterilebilir. Ayrıca malî buhranların yaşanması ile tebaanın yanı sıra ehl-i örf ile ehl-i şer'den bazılarının görevlerini suistimal ederek karaborsacı ve kaçakçılarla işbirliği yapmaları, karaborsacılık ile kaçakçılık olaylarının artmasına yol açmıştı.

Merkezî yönetim, artan karaborsacılık olaylarına karşı bazı önlemler almıştı. Kıtlık zamanlarında karaborsacıların, haksız kazanç sağlamalarını önlemek için narh sistemini devreye sokmuştu. Narh sistemi sayesinde pazar ekonomisi belirlenerek tebaaya zahire, meyve, et gibi temel gida maddelerinin fahiş fiyatlarla satılmasına mani olunmak istenmişti. Böylece pazar ekonomisi kontrol edilerek tebaanın, temel gıda maddelerini temini yoluna gidilmişti. Ancak gerek beşerî gerek ise doğal sebeplere bağlı olarak zahire, meyve, et vs. temin edilmesinde karaborsacılar bazı sorunlar çıkarmışlardı.

Kaçakçılık olaylarında ise devlet ekonomisi doğrudan zarar görmüş aynı zamanda zor temin edilen ürünler aşırı kâr marjıyla küffara satıldığı için tebaa da mağdur olmuştu. Küffara satılması yasak olan stratejik önemdeki emtianın satılması, devlet politikasına da zarar vermişti. Bu bağlamda merkezî yönetim hem karaborsacılara hem de kaçakçılara ağır cezalar vererek mücadele etmişti. Ancak ehl-i örf ile ehl-i şer'den bazılarının karaborsacı ile kaçakçılardan rüşvet alıp kendilerine yeni gelir kapısı oluşturmaları, merkezî yönetimin karaborsacı ve kaçakçılarla mücadelesini sekteye uğratmıştı. Ayrıca karaborsacı ile kaçakçıların elde ettikleri gelirin fazla olması, denizlerin kontrolünün sağlanmasında karşılaşılan zorluklar karaborsacı ile kaçakçılık olaylarının önlenememesinde oldukça etkili olmuştu.

Osmanlı Devleti'nde XVI. yüzyılında karaborsacılık ve kaçakçılık suçları üzerinde yapılan çalışmaların oldukça sınırlı olması, mühimme defterlerine dayanarak böyle bir çalışmanın yapılmasını gerekli kılmıştır.

Anahtar Kelimeler: XVI. Yüzyı1, Merkezî Yönetim, Karaborsacılık, Kaçakçılık, Kıtlık, Cezalar.

\section{ABSTRACT}

Black marketing and smuggling crimes were not seen much in the first half of the sixteenth century in the Ottoman Empire, but they were effective in the second half of this century. The reasons for this were the Ottoman-Austrian Hungary and Iran wars, the breakdown of the laws, and the deterioration of the balance between production and consumption with the migration from rural to urban centers due to the Celali rebellions.In addition, financial crises, the public and some of the men of science and law abusing their duties and cooperating with black marketeers and smugglers led to an increase in black marketing and smuggling incidents.

\footnotetext{
* Dr., Milli Eğitim Bakanlığı, syilmaz3840@ hotmail.com ORCID: https://orcid.org/0000-0002-6979-6495
} 


\section{F. ̈. Sosyal Bilimler Dergisi 2020-30/2}

The central government had taken some measures against increasing black market incidents. In times of scarcity, the Narh System (state determination of prices) was introduced to prevent the black marketeers from gaining unfair profits and the Narh System became the determining factor in the market economy. The Narh System was determinant in the market economy by preventing people from buying basic foodstuffs such as grains, fruits and meat at excessive prices and eliminating socio - economic problems. Thus, the market economy was controlled, and the needs of the people were provided abundantly and cheaply. However, some opportunities emerged for the black marketeers while supplying grains, fruit, meat, etc. for the people depending on both human and natural reasons.

While the state economy was directly damaged in the cases of smuggling, the people were also victims because the scarcity products were sold to foreigners with excessive profit margins. The illegal sale of a strategically important commodity, which was forbidden to sell to foreigners, also undermined state policy. In this context, the central government imposed heavy penalties on both the black marketeers and the smugglers. However, in the fight against these criminal organizations, the fact that some of the men of science and law took bribes from the black marketeers and the smugglers and created new gates of income created weaknesses in the state. In addition, that the income obtained by the black marketeers and the smugglers was high and there were difficulties in controlling the seas and so on made difficult to prevent these crimes.

The fact that the studies on the crimes of black marketing and smuggling in the sixteenth century in the Ottoman Empire were very limited has necessitated such a study based on the Registry Books.

Keywords: Sixteenth Century, Central Government, Black Market, Smuggling, Scarcity, Penalty.

\section{GíRiş}

XVI. yüzyılda Osmanlı Devletin'de stratejik öneme sahip her türlü emtianın ihracı kontrol altında olup ihracı yasaklanmıştı. Özellikle zahire ve bakliyatın yanı sıra sahtiyan, gön, bakır, kükürt ${ }^{1}$ ile savaş araç gereçleri; top, silah, kurşun, barut, at ihracı yasaklı mallar arasında yer almıştı. ${ }^{2}$ Şöyle ki İstanbul ile Budun güzergâhında ki kaza kadılarına gönderilen hükümde küffar ülkelerine stratejik öneme sahip at satılmaması emredilmişti. ${ }^{3}$ Ayrıca "1586'da (995) Macar'a ve Leh'e at ve sı̆̆ır ve koyun verilmeye... "4 şeklinde hükm-i şerif de yayınlanmıştı.

İhracı yasaklanan bu mallar arasında yer alan zahire içinse ülke genelinde tebaanın ihtiyacından fazlasına ihraç izni verilmekteydi. Bunun yanı sıra marjinal faydası sıfır olan emtia ihraç edilirken özel izne tabi olup gümrük vergisi oldukça yüksek tutulmaktaydı. ${ }^{5}$ Bu uygulamanın temel sebebi ise Osmanlı Devleti'nde iaşe kıtlığının yaşanmasıydı. ${ }^{6}$ İhracı yasaklanan maddelerin cinsine bakıldığında stratejik öneme sahip askerî malzemeler, esnafin ihtiyacı olan hammadde ile gıda ve et ürünleri olduğu anlaşılmaktadır.

Osmanlı Devlet politikası, kuruluş yıllarından itibaren ihtiyaç duyulan ürün ve malların tedarikinde ithalata gereksinim duyulmadan kendi kendine yetme anlayışına dayanmaktaydı. Bu bağlamda merkezî yönetim hem devlet işlerinin yürütülmesinde hem de tebaanın ihtiyaçlarının karşılanmasında oldukça itinalı davranmıştı. Tebaanın ihtiyaç duyduğu yiyecek ve giyecek malzemelerinin teminine oldukça önem verilmiş ve herhangi bir kıtlığın yaşanmaması için ihracına müsaade edilmemişti. ${ }^{7}$ Merkezi yönetimce böyle bir ekonomik anlayışın benimsenmesinde; tebaanın gündelik ihtiyaçlarını temin ederken herhangi bir güçlükle karşılaşmaması anlayışının

\footnotetext{
${ }^{1}$ İsmail Hakkı Uzunçarşı1lı, Osmanlı Tarihi, Cilt II, T:T:K Yayınları, Ankara, 2011, s. 686.

${ }^{2}$ Mehmet Ali Ünal, Osmanlı Sosyal ve Ekonomik Tarihi, Paradigma Yayıncılık, İstanbul, 2012, s. 175.

${ }^{3}$ Başbakanlık Devlet Arşivleri Genel Müdürlüğü Osmanlı Arşivi Daire Başkanlığı, 5 Numaralı Mühimme Defteri (973/1565-1566) Özet Transkripsiyon, Ankara, 1994, s. 14.

${ }^{4}$ Mustafa Akdağ, Türk Halkının Dirlik ve Düzenlik Kavgası, II. Baskı, Yap1 Kredi Yayınları, İstanbul, 2013, s. 35.

${ }^{5}$ Mehmet Genç, Osmanlı İmparatorluğun'da Devlet ve Ekonomi, XI. Baskı, Ötüken Neşriyat, İstanbul, 2014, s. 43.

${ }^{6}$ Zafer Karademir, İmparatorluğun Açlıkla İmtihanı Osmanlı Toplumunda Kitlıklar (1560-1660), II. Bask1, Kitap Yayınevi, İstanbul, 2017, s. 11.

7 İsmail Hakkı Uzunçarş1l1, a.g.e., s. 689.
} 
hâkim olmasıydı. ${ }^{8}$ Merkezî yönetimce alınan tedbirlerin taşrada ki bazı devlet memurlarının (özellikle gümrük memurlarının) rüşvet karşıllğında görevlerini suistimal etmeleri, karaborsacılık ve kaçakçılıkla yapılan mücadeleyi kadük hale getirmişti.

XVI. yüzyılda Osmanlı Devletin'de karaborsacılığın yanı sıra özellikle deniz ticaretinde kaçakçılık faaliyetleri devleti oldukça meşgul etmişti. Bu yüzyılda devletlerarası muvazene bozulup gerek denizlerde (İnebahtı Savaşı) gerekse karada (Osmanl1-Avusturya ve İran) savaşlar yaşanmıştı. Savaş ekonomisinin yaşanıp ordunun özellikle gıda başta olmak üzere lojistik malzemelerin (at, yem vs.) temininde güçlüklerin yaşanmas $1,{ }^{9}$ Osmanlı Devleti'nin ticari ambargo koyması, hammadde ve stratejik öneme haiz ürünlerde kaçakçılığın yapılmasını hızlandırmıştı. ${ }^{10}$ Buna bağlı olarak ihtiyaç duyulan emtianın karşılanamaması hem karaborsacılığın hem de kaçakçılığın yapılmasına neden olmuştu.

\section{A) Osmanlı Devletin'de Karaborsacılık}

Osmanlı Devleti, tebaanın gündelik hayatını idame ettirmesinde ana unsur olan zahire, meyve ve et gibi ürünlerin yerinde ucuz ve bol miktarda sağlanması için bazı düzenlemeler yapmıştı. Özellikle ziraî alanda ürünün tarladan pazara kadar geçen evrelerinde her türlü malın alınıp satılmasında esnaf örgütleri ile bunları denetleyen devlet memurları (ehl-i örf ile ehl-i şer') bulunmaktaydı. ${ }^{11}$ Bunlar sayesinde yolsuzluk yapıp haksız kazanç sağlayanlar cezalandırılırdı. ${ }^{12} \mathrm{Bu}$ bağlamda merkezî yönetim istifçilik yaparak haksız kazanç sağlayıp tebaayı mağdur edenlere ağır cezalar vererek mücadele etmişti. Şöyle ki, 1580 yılında Aydın kazasında kara üzüm istifçiliği yapan birine başkentte kasaplık yapma cezası verilmiş ve elindeki kara üzümler alınarak belirlenen fiyatta satılmasına karar verilmişti. ${ }^{13} \mathrm{Bu}$ hükümde açıkça karaborsacılık yapan birine sürgün cezası ile malına el koyma (müsadere) cezalarının verildiği anlaşılmaktadır.

Pazarı denetleyip tebaanın mağdur olmaması için gayret sarf eden merkezî yönetimin aldığ 1 bazı tedbirlere rağmen haksız uygulamalar da olmuştu. Şöyle ki merkezî yönetimin hevayic-i zaruriye yani kıtlığa ${ }^{14}$ karşı sıkı tedbirler almıştı. Buna rağmen kıtlığın yaşandığı dönemlerde zenginlerden bazıları piyasada bulunan, hububat gibi temel gıda maddelerini alıp stoklamışlar ${ }^{15}$ yani der-mahzen etmişlerdi. ${ }^{16}$ Böylece bunlar hem pazarda ürün darlığına hem de kasitlı olarak arz talep dengesini bozarak artan talep karşısında emtianın aşırı artmasına sebep olmuşlardı. Bu işi yapanlara muhtekir ${ }^{17}$ yani karaborsacı denilmişti. Kanuni döneminde; karaborsacılar tarafindan reâyânın hassa arazilerinde elde ettiği mahsulâtın pazarlarda satılmasına izin verilmeyişinin arz edilmesi üzerine bu uygulamaya son verilmesi emredilmişti. ${ }^{18} \mathrm{Bu}$ uygulama ile hem üreticinin ürünlerini satması kolaylaştırılmış hem de tebaanın ihtiyaçlarının sağlanmasına imkân verilmişti.

Merkezî yönetim, tebaanın bol ve ucuza temel gıda maddelerini almaları için fiyat hareketlerini denetleyerek mağduriyetlerin yaşanmamasına dikkat etmişti. Şöyle ki Edirne kadısına

\footnotetext{
${ }^{8}$ Mehmet Ali Ünal, a.g.e., s. 176.

${ }^{9}$ Sam White, Osmanlı'da İsyan İklimi Erken Modern Dönemde Celâli İsyanları, Çeviren: Nureddin Elhüseyni, Alfa Yayınc1lik, İstanbul, 2013, s. 202.

${ }^{10}$ Mikail Acıpınar, Osmanlı İmparatorluğu ve Floransa Akdeniz'de Diplomasi, Tiçaret ve Korsanlık 1453 -1599, Türk

Tarih Kurumu Yayınları, Ankara, 2016, s. 323-324.

${ }^{11}$ Mehmet Genç, a.g.e., s. 42-43.

12 İsmail Hakkı Uzunçarşı11, a.g.e., s. 689-690.

${ }^{13}$ Mehmet Koç, Osmanlı Hukukunda Ta'zir Suç ve Cezaları, Aybil Yayınları, Konya, 2017, s. 254

14 İlber Ortaylı, Türkiye Teşkilât ve İdare Tarihi, III. Baskı, Cedit Neşriyat, Ankara, 2008, s. 303.

${ }^{15}$ Zafer Karademir, a.g.e., s. 13.

16 BOA MD 27, h. 840, s. 350.

${ }^{17}$ Muhtekir: Buğday ve emsali gibi, insanların zaruri ihtiyaçlarını karşılayan maddeleri, muzayaka vaktinde yüksek bedelle satmak için salkıyan kimse hakkında kullanılır. Ayrıntılı bilgi için bakınız: Mehmet Zeki Pakalın, Osmanlı Tarih Deyimleri ve Terimleri Sözlüğ̈̈, Cilt: II, Milli Eğitim Yayınları, İstanbul, 1946, s. 571.

${ }^{18}$ Ömer Lûtfi Barkan, XV ve XVI ıncı Asırlarda Osmanlı İmparatorluğunda Ziraî Ekonominin Hukukî ve Malî Esasları, Yayına Hazırlayan: Hüseyin Özdeğer, I. Cilt, Kanunlar, İstanbul, 2001, s. 44.
} 


\section{F.Ü. Sosyal Bilimler Dergisi 2020-30/2}

Edirne ve civarında etin vukiyye ${ }^{19}$ sinin üçer akçeye satılmasına dair pek çok hüküm gönderildiği buna rağmen yedişer ya da sekizer akçeye satılarak başkentte et sıkıntısı yaşanmasına sebep olduğu belirtilerek bu uygulamaya son vermesi emredilmişti. ${ }^{20}$ Pazar fiyatlarının denetimi yapılarak herhangi bir ürünün fahiş fiyatla tebaaya satılmasına mani olunup başkentteki tebaanın da et ihtiyacının karşılanmasına çalışılmıştı.

XVI. yüzyılın ikinci yarısından sonra Osmanlı toprak düzeninde önemli bir yere sahip olan timar sisteminin bozulmasıyla, köylülerin iktisadî ve sosyal hayatını yeniden tanzim eden bir yapının kurulmasında zorluklar yaşanmıştı. ${ }^{21}$ Tarıma dayalı ekonomik yapı içerisinde köy hayatının Celâli isyanlarıyla da yaşanmaz hale gelmesi, ${ }^{22}$ köylerde göçlerin yaşanmasına neden olmuştu. Böylece tarım ve tarıma bağlı (hayvancılık, bahçecilik vs.) alanlarda da hâsılat düşüklüğü yaşanarak tebaa kıtlıkla karşı karşıya kalmış ve pahalılık yaşanmıştı. ${ }^{23}$ Bunun yanı sıra iklimsel koşullara bağlı olarak yaşanan sorunlarda hâsılatın düşmesinde bire bir etkili olmuştu. ${ }^{24} \mathrm{Bu}$ gibi sebepler de üretimin, tüketimi karşılayamamasına yani arz-talep dengesinin bozulmasına yol açmıştı. Bu bağlamda merkezî yönetim, karaborsacılığı önlemek için bazı tedbirler almış olsa da karaborsacılık, tüketimin aşırı baskısı nedeniyle önlenememişti.

\section{B) Karaborsacılığın Sebepleri}

a) Arz-talep Dengesinin Bozulması

Osmanlı iktisat politikasının esası arz-talep dengesinin sağlanmasına yönelikti. Merkezî yönetim bir yandan üretime dayalı ticarî hayatı canlı tutmayı amaçlamışken diğer yandan da tebaanın gündelik ihtiyaçlarını zorluk çekmeden temin etmesi için gayret etmişti. Bunun için arztalep dengesinin bozulmamasına oldukça dikkat etmişti. Ancak tarımsal ve hayvansal ürünlerin elde edilmesinde bazı zorluklar yaşanmıştı. ${ }^{25}$ Şöyle ki bölgeler arası ulaşım ağlarının gelişmemiş olması ile ulaşımın pahalı yapılması gibi sorunlar bölgesel kıtlıkların görünmesinde etkili olmuştu. 26

Arz-talep dengesinin bozulmasının başka bir sebebi ise ehl-i örf ile ehl-i şer'den bazılarının karaborsacılık yapmalarıydı. Bunlar, bulundukları kazalarda, sancak ve eyaletlerde ürünlerin çok ve ucuz olduğu zamanlarda alarak stok yaparlar, kitlık zamanlarında ise ucuza alıp stokladıkları ürünleri istedikleri fiyatlara satarak tebaaya zulüm yapmaktaydılar. ${ }^{27}$ Arz-talep dengesinin bilinçli olarak bozulması, haksız kazanç kapılarını aralamakta ve pazar ekonomisinde ürün ve para sirkülasyonuna zarar vermekteydi. Bu durum aynı zamanda kıtlı̆̆ yaşanan emtia ya da ürün fiyatlarının artmasına yol açmaktayd. ${ }^{28}$

\section{b) Kırsaldan Kentlere Göçler}

XVI. yüzyılda kırsal bölgelerden kentlere doğru yapılan göçler sebebiyle şehirli halkın temel gıda ürünlerinin sağlanmasında bazı sorunlar yaşanmıştı. Celâli isyanlarına bağlı olarak köylerin

\footnotetext{
${ }^{19}$ Vukiyye ( Bkz: Kıyye): Okka adlı eski ağırlık ölçüsünün diğer ismi olup 400 dirhemde ibaretti. Buna ukiyye veya vukiyye denir. Ayrıntılı bilgi için bakınız: Mehmet Ali Ünal, Paradigma Osmanlı Tarih Sözlüğü, Paradigma Yay., İstanbul, 2010, s. 404.

${ }^{20}$ BOA MD 69, h. 77, s. 44-1.

${ }^{21}$ Mustafa Cezar, Osmanlı Tarihinde Levendler, Çelikcilt Matbaası, İstanbul, 1965, s. 191.

${ }^{22}$ Mustafa Cezar, a.g.e., s. 195.

${ }^{23}$ Süleyman Demirci, Hasan Arslan, Osmanlı Türkiyesi’nde Eşkıya, Devlet ve Siyaset, Yalın Yayıncılık, İstanbul, 2012, s. $150-151$.

${ }^{24}$ Savaş YILMAZ, "XVI. Yüzyılın İkinci Yarısında Üretimden Pazara Osmanlı Köylüsünün Karşılaştığı Yapısal Sorunlar ve Bu Sorunlara Karşı Merkezî Yönetimin Aldı̆̆ı Tedbirler”, Vakanivus - Uluslararası Tarih Araştırmaları Dergisi/International Journal Of Historical Researches, Say1: 4, 2019, ss. 746-778, s. 754.

${ }^{25}$ Savaş YILMAZ, a.g.m., s. 764.

${ }^{26}$ Mehmet Genç, a.g.e., s. 42,

${ }^{27}$ Gelibolulu Mustafa Âli, Siyaset Sanatı Nushatü's-Selâtîn, Hazırlayan: Faris Çerçi, Büyüyenay Yayınları, İstanbul, 2015, s. 189.

${ }^{28}$ Zafer Karademir, a.g.e., s. 13.
} 
viraneye dönmesi, merkezî yönetim için ciddi sorun olmuştu. Bu durum XVI. yüzyılın ikinci yarısında daha belirgin hale gelmiş ve pek çok köy terk edilmişti. ${ }^{29}$ Köylerin çeşitli nedenlere bağlı olarak terk edilmesi kent halkının ihtiyaç duydukları gıda ürünleri başta olmak üzere bazı hammaddelerin temininde de zorluklar yaşamasına neden olmuştu. Osmanlı Devleti'nde köy yerleşkeleri ile onların hinterlandı olan kentler arasında güçlü bir bağ bulunmaktaydı. Özellikle kentlerin doyurulmasında bu bağ ve ilişkinin daha güçlü olduğu anlaşıllır. ${ }^{30} \mathrm{Bu}$ bağlamda kırsaldan kentlere yapılan göçler merkezî yönetim için sosyo-ekonomik sorunları da beraberinde getirmişti. Herşeyden önce tarım ve tarıma bağlı ürünlerin yetiştirilmesinde ve arz-talep dengesi, talep lehine bozulmuştu.

Artan talebe rağmen arzın yetersiz kalması özellikle eşkıyalık bağlamında XVI. yüzyılın ikinci yarısında karaborsacılığın artmasına yol açmıştı. Bu dönemde eşkıyalar, ekinliklere sürülerini soktukları gibi harman yerlerini soyup ${ }^{31}$ yakmışlard. ${ }^{32}$ Bunun gibi köylülerin zahirelerini eşkıyalar zorla alarak, ${ }^{33}$ evlerini ateşe verip,,$^{34}$ bağ ve bahçeleri ${ }^{35}$ ile koyunlarını da cebren alıp mallarını yağmaladıkları gibi cinayetlerde işlemişlerdi. ${ }^{36}$ Ayrıca eşkıyalar, köylülerin öküz, inek ${ }^{37}$ gibi tarım arazilerinin işlenmesinde gücünden faydalanılan hayvanlarını, ellerinden zorla almışlardı. Bu şekilde köylülerin tarım arazilerini işlemelerinde zorluklar yaşamalarına neden olmuşlardı. Tarım arazilerinin işlenmesinde görülen zorluklar tarımsal üretimi de olumsuz yönde etkilemişti. Eşkıyalar, köylülerin ekili dikili arazileri ile harmanlarına zarar vermekle kalmamışlar, mandıralarını basıp cinayet işlemiş̧lerdi. Eşkıyalar üretimi doğrudan etkileyen kanunsuzluklarının yanı sıra, köylülerin çocuklarını esir alıp küffara satmışlar kadınlarına, oğul ve kızlarına da tecavüz ederek çeşitli zulümler yapmışlardı. ${ }^{38}$

XVI. yüzyılın ikinci yarısında eşkıyalık bağlamında köylülerin, can, mal ve namus güvenliği kalmamıştı. Bunun yanı sıra tarım alanlarında iklimsel nedenlere bağlı kuraklık ile don olayları yaşanması, tarım arazilerinin çekirge istilasına uğraması gibi nedenlere bağlı olarak mahsûl azalmıştı. ${ }^{39}$ Bütün bu olumsuzluklarla beraber köy nüfusunun 1520-1576 yılları arasında aşırı artmas1, kıt kaynaklarla artan nüfusun beslenip evlendirilmesi, köylü ailelerin ana sorunları arasında yer almıştı. Evlenecek çağda ki genç nüfusun maddi zorluklarla baş başa kalması kır yerleşkelerinden şehirlere doğru göçü tetiklemişti. ${ }^{40} \mathrm{Bu}$ nedenlere bağlı olarak kır yerleşkeleri boşalarak viraneye dönmüştü. Bu durumun doğal sonucu olarak şehir nüfusunun artmasiyla beraber başta temel gıda ürünleri olmak üzere pek çok emtiada kıtlık ya da darlık yaşanmıştı. Üretim yaşanan olumsuzluklara bağlı olarak düşmüş bunun sonucu olarakta pazarda bir darlık/kitlık meydana gelmişti. Emtianın ihtiyacı karşılayamamasının yanı sıra karaborsacıların istifçilik yapıp emtia fiyatlarını artırmaları, tebaanın gündelik hayatını idame ettirmesinde sorunlar yaşamasına yol açmıştı.

\section{c) İklimsel Koşulların Tarım Arazilerini Olumsuz Etkilemesi}

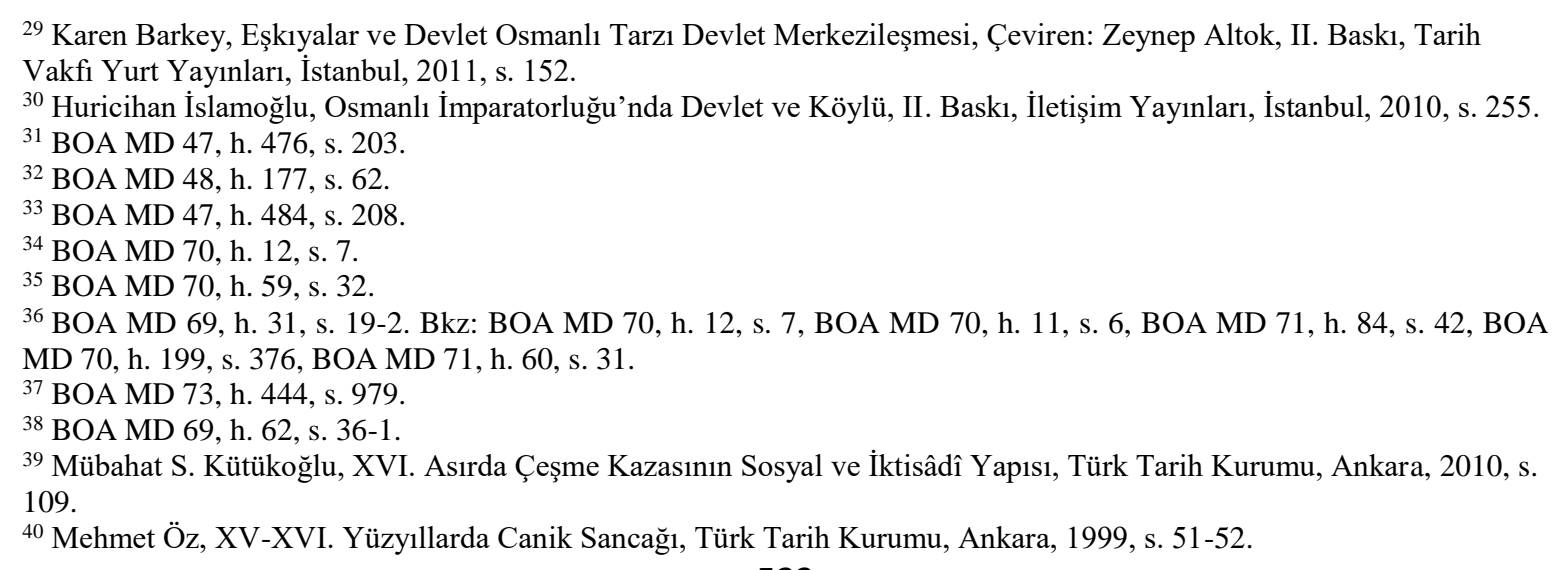


XVI. yüzyılda yaşanan iklimsel faktörlere bağlı kuraklık, don, aşırı soğuk gibi hava koşullarının yaşanması, tarım alanlarından birim arazide elde edilen hâsılatı olumsuz yönde etkilemişti. Özellikle köylerin suya olan ihtiyaçları tarımsal ürünler üzerinde doğrudan etkili olmaktaydı. Yanbolı kadısına gönderilen hüküm de Çeri (?) köyünün su ihtiyacının karşılanması için nehrin suyunun köye akıtılması için gerekli tedbirlerin alınması emredilmişti. ${ }^{41}$ Devamında 1591-1595 ile 1592-1596 yılları arasında yaşanan kuraklık, kırsal hayatı doğrudan etkilemişti. Kuraklığa bağlı olarak şehirlerde su sıkıntıları yaşanmış ve kırsaldaki tarım arazileri de bu kuraklıkta olumsuz etkilemişti. Bu nedenle bölgesel bazda kıtlıklar ya da darlıklar yaşanmıştı. ${ }^{42}$

İklimsel koşullara bağlı yaşanan kıtlık ya da darlığa merkezî yönetimce tarım alanlarının ıslahına yönelik ciddi tarımsal çalışmaların yapılmayışı da tarım alanlarında elde edilen ürünlerde bir rekolte kaybının yaşanmasına yol açmıştı. Osmanlı tarımının iklimsel ve kronik sorunlarının yanı sıra tarlalarda çekirge istilalarının görülmesi de yıllık ürün kaybına yol açmıştı. Devlet, çekirge istilasına yönelik çekirge yumurtalarının itlaf edilmesini taşradaki yöneticilere emretmişti. ${ }^{43}$ Böylece ürün rekoltesinde yaşanacak zararların önü alınmaya çalışılmıştı. Ancak alınan tedbirlerin oldukça sınırlı olması tarımsal rekoltenin düşmesine mani olamamıştı.

Osmanlı köylüsünün yapısal sorunlarının yanı sıra iklimsel koşullardan kaynaklanan sorunları tarım arazilerinde yeterince istifade edilmesine mani olmuştu. Şöyle ki iklimsel sebeplerde kaynaklanan kitlıklar zaman zaman köylünün bir sonraki sene için tohumluk dahi bulmasını zora sokmaktaydı. ${ }^{44}$ Köylü tarımsal arazilerde marjinal fayda sağlayamadığ kuraklığa bağlı yaşadığı sorunlar nedeniyle de tohumluk bulmakta zorluklarla da karşı karşıya kalmıştı.

\section{d) Tüccar ve Esnafların Kâr Marjlarını Artırmak İstemeleri}

Tüccar ve esnafların ellerindeki emtiadan daha fazla kâr etme arzuları her dönemde hâkim anlayış olmuştu. Ancak tüccar ve esnafların aşırı kâr marj anlayışları, merkezî yönetimin arz ile talep arasinda fiyat hareketlerini denetleyen narh sistemi belirlemekteydi. Fiyat hareketlerinin denetlenmesinden çarşı ve pazarların kontrol edilmesine kadar bazı görevler muhtesiplerin sorumluluğundaydı. ${ }^{45} \mathrm{Bu}$ şekilde emtia fiyatlarının aşırı pahalanmasının önü alınıp tebaanın mağdur olmasının önüne geçilmekteydi. Yani emtia fiyatlarının belirlenmesi devletin kontrolü altındaydı. Böylece hem üretici ve satıcılar korunurken hem de tebaanın alım gücünün, fiyat artışlarına bağlı olarak, düşmesine mani olunuyordu. Buna rağmen yaşanan herhangi bir savaş hali, kuraklık, salgın gibi felaketlerin olduğu zaman da tüccar ve esnaflardan bazıları bu durumu lehlerine çevirerek ürünler üzerinde istedikleri kârları sağlamaktaydılar. Bu bağlamda İstanbul kadısına gönderilen hüküm de Mısır'da tüccar ve gemicilerin getirdikleri pirincin sur içine stoklandığı bu sebeple piyasada pirinç darlığı oluştuğundan dolayı tebaaya fahiş fiyatla pirinç satıldığı belirtilerek narhı cari üzerinde pirinç satılmaması emredilmişti. ${ }^{46}$ Fiyatların aşırı artması tebaanın hem alım gücünü düşürmekte hem de ihtiyaç duyulan ürünlerin elde edilmesinde sorunlar yaşanmasına neden olmaktaydı. Bu bağlamda sadece kendi çıkarlarını düşünen gemi kaptanlarının, küffara satılmaması gereken ürünleri satarak pazarda ürün darlığının/kıtlığının yaşanmasında da etkileri olmaktaydı. Şöyle ki tüccar ve gemiciler tarafindan İstanbul'a götürülmesi gereken yapağı, gön ve sahtiyanın Gelibolu, Silivri, Tekfurdağ İskelelerine götürülerek küffara satılmasından dolayı bu malzemelerin temininde zorluklar yaşanmıştı. ${ }^{47}$ İtiyaç duyulan emtianın bulunmasında yaşanan

\footnotetext{
${ }^{41}$ BOA MD 48, h. 249, s. 92.

${ }^{42}$ Sam White, a.g.e., s. 196-197.

${ }^{43}$ Mustafa Akdağ, a.g.e., s. 72.

${ }^{44}$ Mehmet Ali Ünal, a.g.e., s. 100.

${ }^{45}$ Ziya Kazıcı, Osmanlı'da Yerel Yönetim (İhtisab Müessesesi), Bilge Yayınevi, İstanbul, 2006, s. 91.

${ }^{46}$ Başbakanlık Devlet Arşivleri Genel Müdürlüğü Osmanlı Arşivi Daire Başkanlığı, 7 Numaralı Mühimme Defteri, s. 750.

${ }^{47}$ Başbakanlık Devlet Arşivleri Genel Müdürlüğü Osmanlı Arşivi Daire Başkanlığı, 7 Numaralı Mühimme Defteri, s. 861.
} 
zorluklar nedeniyle karaborsacılar, istifledikleri bu ürünleri aşırı fiyatlarla satarak haksız kazanç elde etmişlerdi.

Osmanlı Devleti'nde sadece hububat ve hububata bağlı ekmek gibi ürünlerin stokçuluğu/karaborsacılığı yapılmamış; aynı zamanda, karaborsacılarca meyve azlığının yaşandığı dönemlerde meyveler stoklanıp fahiş fiyatlarla satılmıştı. Osmanlı Devleti'nde yaşanan büyük tağşişin ardında $(1585)^{48}$ karaborsacılar meyveleri istiflemişlerdi. Bunun sonunda meyve kıtlığının yaşanması üzerine Ege bölgesindeki kadılara gönderilen hükümde aracılara meyve satılmaması gerektiği, meyvelerin doğrudan gemi reislerine verilmesi emredilmişti. En büyük üzüm tedarikçileri arasında yer alan Ege bölgesinde dahi bir kantar üzüm fiyatının 40 akçeden 120 akçeye çıkması, piyasada üzüm darlığına yol açmıştı. ${ }^{49}$

Fiyatların aşırı artması karşısında tebaa başta olmak üzere zaman zaman merkezî yönetim dahi başkentin temel gıda ürünlerini sağlamak da zorlanmışlardı. Muhtekirler/karaborsacılar ise yaşanan kıtlık ya da darlık zamanında stokladıkları ürünleri aşırı fiyatlara satarak zenginleşmişlerdi.

\section{e) Ehl-i Örf ile Ehl-i Șer’in Karaborsacılık Yapmaları}

Esnaf ve tüccarların yanı sıra ehl-i örf ile ehl-i şer'den bazıları da karaborsacılık yaparak tebaaya ekonomik yönden zarar verdikleri gibi sattıkları ürünler üzerinde de vergi vermeyerek hazineyi gelir kaybına da uğratmışlardı. XVI. yüzyılın ikinci yarısında savaş ekonomisinin uygulandığı yıllarda ekonomik yönden de Osmanlı maliyesi ciddi sorunlarla karşılaşmış; uzun süren savaşlar gıda stoklarını bitirmişti. Üretimin önünde en büyük engellerden biri olan köylerin boşalması ile de kentlerin doyurulması, merkezî yönetimi oldukça meşgul etmişti. ${ }^{50}$

Başkentin iaşesinin sağlanması doğrudan merkezî yönetimin sorumluluğundayken taşradaki büyük şehirlerin iaşesi kadıların sorumluluğundaydı. Buna rağmen zaman zaman başkentte dahi başta buğday olmak üzere meyve ve sebze kıtlı̆̆ı/darlı̆̆ 1 yaşanmış; kadılar, kanunen kendilerine verilen hububat toplama yetkisinde dahi yolsuzluklar yapmışlard. ${ }^{51} \mathrm{Bu}$ bağlamda İznikmid, Sapanca, Bolu ve Kurşunlu kadılarının narh-ı cârî üzere zahire, pirinç satın aldıkları ancak İznikmid kadısının tüccarların satın aldıkları pirinçlere el koyduğu divâna arz edilmesi üzerine İznikmid kadısının pirinci tüccara teslim edip küffara satmaması emredilmişti. ${ }^{52}$ Bunun yanı sıra yeniçerilerin de yaptıkları karaborsacılığa bağlı olarak da fiyat artışları yaşanmıştı. ${ }^{53}$ Doğal nedenlere bağlı olarak kıtlığın/darlığın yaşandığı dönemlerde dahi madrabazlar başta olmak üzere timarlı sipahiler, ümera gibi devlet memurları, Avrupa'ya buğday kaçakçılığı yapmışlardı. ${ }^{54}$

Karaborsacılar hakkında XVI. yüzyılın ikinci yarısında sayısız arzlar Divân-ı hümâyûna sunulmuştu. Bu bağlamda Bursa kadısı Divân-1 hümâyûna gönderdiği arz da bakkalların mahkemeye gelerek Pazarcıbaşı Mahmut'un, şehre zahire getirenlerin elindeki zahireyi alıp ambara stokladığını ve bakkallardan akçe almadıkça vermediğini, yaşanan zahire darlı̆̆ından dolayı tebaa ile bakkal esnafinın huzursuz olduğunu ve Pazarcıbaşı Mahmut'un bu şekilde on bir yıl karaborsacılıkla haksız kazanç sağladığını belirtmişti. ${ }^{55}$ Şam beylerbeyi ie Safed kadısına gönderilen hükümde Safed halkının Divân-1 hümâyûna arz-i hal sunarak köylülerin, zahire, un gibi ürünlerini şehre götürüp hem halka hem de tüccarlara satarak geçimlerini sağlarken muhtesip ile ümenanın anlaşıp tekelleşerek kendilerinin haricinde zahire, un gibi ürünleri sattırmadıklarını ve

\footnotetext{
48 Şevket Pamuk, Osmanlı İmparatorluğu'nda Paranın Tarihi, Türkiye İş Bankası Kültür Yayınları, İstanbul, 2017, s. 136.

49 BOA MD 53, h. 469, s. 160.

${ }^{50}$ Sam White, a.g.e., s. 203.

${ }^{51}$ Mustafa Akdağ, a.g.e., s. 73.

52 BOA MD 27, h. 866, s. 363.

${ }^{53}$ Sam White, a.g.e., s. 205.

${ }^{54}$ Mustafa Akdağ, a.g.e., s. 71.

${ }^{55}$ BOA MD 73, h. 1002, s. 454.
} 


\section{F.Ü. Sosyal Bilimler Dergisi 2020-30/2}

kendilerinin ise bu ürünleri aşırı fiyata satarak halka zulüm ettiklerini arz etmişlerdi. ${ }^{56}$ İskenderiye beyine gönderilen hükümde ise Dukakin, Prizren, İskenderiye sancaklarının hassa emini Ahmet beyin göndermiş olduğu arz da Frenk Beyi Nakşa'nın, Dukakin sancağına bağlı Beneste sahiline yakın bir yere yerleşerek tebaada topladığı emtiayı ambara stoklayıp Frengistan'a sattığını belirtmişti. Bu hususta hem karaborsacılık hem de kaçakçılık yapan Nakşa adlı zimminin yakalanıp başkente gönderilmesi emredilmişti. ${ }^{57}$ Genelde karaborsacılık iç pazarda emtia kıtlığının yaşandığ 1 zamanlarda fiyatların artmasına bağlı yapılmaktaydı. Burada ise stokçuluk, iç pazara yönelik yapılmayarak uluslararası boyutta yapıldığı anlaşılmaktadır.

Merkezî yönetim, karaborsacılarla mücadeleyi daha etkin kılmak için; müsadere cezası başta olmak üzere, falaka, siyaseten katl, sürgün ve hapis cezaları vermişti. ${ }^{58}$ Merkezî yönetimce, karaborsacılık yapan ehl-i şer' ile ehl-i örfe verilen cezaların ağır yaptırımlar ihtiva ettiği görülmektedir.

\section{C) Osmanlı Devletin'de Kaçakçılık}

XVI. yüzyılda Osmanlı Devleti'nin kurumsal yapısının pazar ekonomisini belirleyip yönlendirecek iktisadi unsurlara sahip olması, üretim ile tüketim arasında dengenin bozulmamasına gayret etmesi, tebaanın muhtelif ihtiyaçlarını karşılanmasına yönelik tedbirlerdendi. Merkezî yönetim enflasyonun, tebaanın alım gücünü etkilememesi için narh sistemine önem vermişti. Narh sistemine göre esnaf ile tüccarın kâr marjı \%5 ile \%15 arasında belirlenmişti. Belirlenen oranlardan fazla kâr sağlamak isteyenlere ağır cezalar verilmişti. ${ }^{59}$

XVI. yüzyıl boyunca devletin, iktisat politikas1; ithalatı serbest bırakarak ihracatı kısıtlayıp kontrol altında tutmaya dayanmaktaydı. Devletin, bu iktisat politikası XIX yüzyılın ikinci yarısına kadar sürmüştü. $\mathrm{Bu}$ politika gereğince ihracat ürünlerine yüksek vergiler konmuş hatta yasaklamalara kadar giden kanunî düzenlemeler yapılmışt1. ${ }^{60}$ Elinde emtia bulunan tebaadan ya da devlet memurlarından (ehl-i örf ile ehl-i şer') bazıları daha yüksek kâr elde etmek için devlet politikasına mugayir hareket ederek kaçakçılık yapmışlardı.

Osmanlı tebaası tarafindan altın, gümüş gibi madenlerin hammadde ya da yarı mamul madde olarak Avrupa'ya yüksek fiyatlarla satıldığ ${ }^{61}$ gibi Sana'dan Hindistan'a gümüş kaçakçıllı̆g ${ }^{62}$ da yapılmaktaydı. Çeşitli emtiaların yanı sıra zahire, üzüm gibi gıda ürünleri de kaçakçılar vasıtasıyla küffara satılmaktaydı. Bu bağlamda zahire stratejik bir ürün olduğu için bunun alınıp satılmasına merkezî yönetimce oldukça dikkat edilmişti. Buna rağmen daha fazla kâr elde etmek isteyenlerce, bu ürün küffara kaçak olarak satılmıştı. Mihalıç, Aydıncık, Gönen ve Manyas kadılarına gönderilen hüküm de köylülerden, İstanbul'a gönderilmek için develerle toplanan zahirenin kara yoluyla limanlara taşınarak kaçak yollarla küffara satıldığı belirtilip gerekli tedbirleri almaları emredilmişti. ${ }^{63}$ Bunun gibi Kite kazasına bağlı Eriklü ile Yalak-âbâd kazasına bağlı Gonca köylüleri, İstanbul'un her yıl önemli miktarda üzüm ihtiyacını karşılanırken, köylüler ürünlerinde daha çok kâr sağlamak için küffara kaçak yollarla satmışlardı. ${ }^{64}$ İzmir ve Foça kadılarına gönderilen hüküm de ise Venedik ile diğer ülke gemilerine satılması yasak olan tereke ile kuru

\footnotetext{
${ }^{56}$ BOA MD 51, h. 67, s. 29.

${ }^{57}$ BOA MD 47, h. 92, s. 36.

${ }^{58}$ Mehmet Koç, a.g.e., s. 251.

${ }^{59}$ Mehmet Genç, a.g.e., s. 47.

${ }^{60}$ Mehmet Genç, a.g.e., s. 50.

${ }^{61}$ Mehmet Ali Ünal, a.g.e., s. 176.

${ }^{62}$ Başbakanlık Devlet Arşivleri Genel Müdürlüğü Osmanlı Arşivi Daire Başkanlığı, 5 Numaralı Mühimme Defteri, s. 276.

${ }^{63}$ Başbakanlık Devlet Arşivleri Genel Müdürlüğü Osmanlı Arşivi Daire Başkanlığı, 6 Numaralı Mühimme Defteri, s. 47.

${ }^{64}$ Başbakanlık Devlet Arşivleri Genel Müdürlüğü Osmanlı Arşivi Daire Başkanlığı, 6 Numaralı Mühimme Defteri, s. 46.
} 
meyvenin satılmasından dolayı bu ürünlerin temininde zorluklar yaşandığı belirtilerek gerekli önlemleri almaları emredilmişti. ${ }^{65}$

Osmanlı Devleti'nde gerek dâhilî gerek ise haricî sebeplere bağlı olarak XVI. yüzyılda kaçakçılık suçları işlenmişti. Merkezî yönetimin kaçakçıllk olaylarını önleyememesinde; kaçakçıların sattıkları mal ve ürünlerin vergilerini devlete vermeyerek karlı çıkmaları ile sattıkları ürünleri daha pahalıya satmaları etkili olmuştu.

D) Kaçakçılığın Sebepleri

a) Ticaret Yollarının Denetiminin Sağlanmasında Yaşanan Zorluklar

Osmanlı Devletin'de, kaçakçılık en çok deniz yolları kullanılarak yapılmıştı. ${ }^{66}$ Bu bağlamda Osmanlı denizciliğinde gemiciliğin yeterince gelişmemiş olmasının yanı sıra İnebahtı deniz (1571) savaşının kaybedilmesi, Akdeniz'in kontrol edilmesinde zorlukların yaşanmasına yol açmıştı. ${ }^{67}$ Anadolu örneğinde de olduğu gibi limanları iç bölgelere bağlayan karayollarının elverişsiz olması ${ }^{68}$ ve deniz ticaretinin genellikle yabancı gemilerle yapılmış olmas ${ }^{69}$ gibi sebepler deniz yolarında kaçakçılığın daha çok yapılmasına yol açmıştı. Özellikle Rodos ve Lindos Adalarındaki gemi reislerine gönderilen hükümlerde yabancı tacirlere hububat satılmaması gerektiğine yönelik sayısız hükümler bulunmaktadır. ${ }^{70}$ Ege Adalarındaki gemicilerin kaçakçılık yaptığı merkezî yönetimce de bilinmesine rağmen bu menfur fiili önleyici ciddi tedbirler de alınamamıştı. Marmara, Ege ile Rumeli limanlarında yapılan kaçakçılık olayları buralarda daha çok istenilen emtianın elde edilmesinde sorunlara neden olmuştu. ${ }^{71}$

1591 yılından itibaren Karadeniz, Ege ve Akdeniz üzerinde kaçakçılık olayları oldukça artmıştı. ${ }^{72} \mathrm{Bu}$ bağlamda Ege Denizinde olduğu gibi Karadeniz üzerinde yapılan deniz ticaretinde de kaçakçılık oldukça sık yapılmaktaydı. Karadeniz ticaretinde Abazalar ve Mingrelistanla yapılan ticaret büyük ölçüde kaçakçılığa dayanmaktaydı. Özellikle Abazalara silah kaçakçılığı yapılmaktaydı. Osmanlı Devleti, deniz yolları üzerinden Abazalara yapılan kaçak yoldan silah satışını önlemek için Abazalara ticareti yasaklamıştı. ${ }^{73}$ Bunun gibi Karadeniz üzerinde Osmanlı Devleti'ne bağlı Kırım Hanlığı'na gönderilecek kilar mühimmat sevkiyatı sırasında bakır gibi harp sanayisinin ihtiyacı olan mamullerinin kaçak gönderilmemesine oldukça dikkat edilmişti. ${ }^{74}$ Merkezî yönetimce alınan bütün önlemlere rağmen denizlerin denetiminde yaşanan zorluklardan dolayı stratejik öneme sahip mamuller başta olmak üzere çeşitli emtia kaçak yollarla satılmıştı.

Osmanlı Devletinde kaçakçılık sadece deniz yolları üzerinde yapılmamıştı. Deniz yolları kullanılarak yapılan hububat kaçakçıllğının yanı sıra Tuna Nehri üzerinden Polonya'ya ve Doğu illerinden Batı Anadolu'ya kadar kaçak olarak koyun satılması hem deniz yolunun hem de kara yolunun kaçakçılıkta kullanıldığının kanıtıdır. ${ }^{75}$ Bunun gibi Balkanlar ile Anadolu güzergâhında ki karayolunda da koyunlar ${ }^{76}$ ve ihracı yasak olan stratejik öneme sahip atlar da satılmıştı. Bu bağlamda Tırhala ile Nar' kadılarına gönderilen hükümde Tırhala reâyâsından Cemşid'in, küffara at sattığ ve bu sebeple Çemşid hakkında tahkikatın yapılarak neticesinin arz edilmesi

\footnotetext{
${ }^{65}$ Başbakanlık Devlet Arşivleri Genel Müdürlüğü Osmanlı Arşivi Daire Başkanlığı, 7 Numaralı Mühimme Defteri, s. 186.

${ }^{66}$ Ahmed Güner Sayar, Osmanlı İktisat Düşüncesinin Çağdaşlaşması, II. Baskı, Ötüken Yayınevi, İstanbul, 2000, s. 142.

67 İlber Ortayl1, a.g.e., s. 246.

${ }^{68}$ Surayya Faroqhı, Osmanlı'da Kentler ve Kentliler, Çeviren: Neyyir Berktay, V. Baskı, Tarih Vakfı Yurt Yayınları, İstanbul, 2011, s. 95.

${ }^{69}$ Ahmed Güner Sayar, a.g.e., s. 142.

${ }^{70}$ Suraiya Faroqh1, a.g.e., s. 105.

${ }^{71}$ Mustafa Akdağ, a.g.e., s. 35.

${ }^{72}$ Sam White, a.g.e., s. 203.

${ }^{73}$ Surarya Faroqh1, a.g.e., s. 108.

${ }^{74}$ BOA MD 49, h. 449, s. 113.

${ }^{75}$ Sam White, a.g.e., s. 215-216.

${ }^{76}$ Sam White, a.g.e., s. 204.
} 


\section{F.Ü. Sosyal Bilimler Dergisi 2020-30/2}

emredilmişti. ${ }^{77}$ Savaş araç ve gereçlerinin de satılması kanunen yasak olmasına rağmen Şam'da, tüccarlar başta İran olmak üzere küffara silah ve savaş malzemeleri sattıkları belirtilip Beylerbeyi tarafından gerekli tedbirlerin alınarak kaçakçılığa mani olunması emredilmişti. ${ }^{78}$

Merkezî yönetim her ne kadar deniz yolu kullanılarak yapılan kaçakçılığa mani olmak istemiş olsa da denizlerin kontrol altında tutulup denetlenmesi oldukça zor olmuştu. Aynı zamanda devlet memurlarının (ehl-i örf ile ehl-i şer'in) kaçakçılarla işbirliği yapmaları ile beşerî ve doğal faktörlerin kontrolünde yaşanan sorunlar, kaçakçılık olaylarının engellenememesinde etkili olmuştu.

\section{b) Ehl-i Örf ile Ehl-i Şer’in Görevlerini Suistimal Etmeleri}

Ahmet Refik'in de belirttiği gibi gümrük eminlerinin ya doğrudan ya da dolaylı olarak kaçakçıllk olayları içerisinde bulunmaları bu menfur fiiliyatın sürüp gitmesine sebep olmuştu. ${ }^{79}$ Bunun gibi ehl-i örf ile ehl-i şer'lerden bazıları kaçakçılarla işbirliği yaparak görevlerini suistimal etmişlerdi. Şöyle ki Agrıboz beyi ile Atina kadısına gönderilen hükümde ise Muhtesib Memi'nin Espine köyündeki çiftliğinde, küffara buğday sattığının ihbar edildiği, bunun üzerine kanuna aykırı davranıp davranmadığının araştırılması gerektiği, şayet suçunun sabit olması halinde tutuklanarak siciliyle başkente gönderilmesi emredilmişti. ${ }^{80}$ Osmanlı Devleti'nde sadece hububat kaçakçılığ yapılmamıştı. Hububat kaçakçıllğının yanı sıra devletteki nüfuzunu kullanan ehl-i örf ile ehl-i şer'den bazıları, odun kaçakçılığı da yapmışlardı. Şöyle ki Sapanca ve İzmit ormanlık alanlarına kaçak olarak Rumeli'de gelip yerleşen baltacılar, ${ }^{81}$ izinsiz kestikleri ağaçları devlet memurlarıyla işbirliği yaparak Mısır'a kaçak satmışlardı. ${ }^{82}$ İskenderiye beyine gönderilen hüküm de ise kale muhafızlarından bazıları, düşmana satılması yasak olan atları köylülerden satın alıp besledikten sonra düşmana sattıkları arz edilmesi üzerine kaçakçıların dirliklerinin ellerinden alınarak suç dosyaları ile başkente gönderilmeleri emredilmişti. ${ }^{83}$

Tebaanın kaçakçılık yapmasında görevini suistimal eden bazı devlet memurları ile işbirliği halinde bulunmaları, merkezî yönetimin taşraya göndermiş olduğu hükümlerin işlerliğini kadük hale getirmişti. Bu yüzden kaçakçılık, Osmanlı Devleti'nin muhtelif dönemlerinde ehl-i örf ile ehl-i şer'in geçim kapısı olmuştu.

\section{c) Malî Buhranların Kaçakçılık Olaylarına Etkisi}

XVI. yüzyılda doğal ve beşerî faktörlere bağlı olarak yaşanan fiyat artışlarını aynı zamanda uzun süren savaşlarda tetiklemişti. Köylerin boşalmas ${ }^{84}$ üretimi olumsuz etkilerken aralıklarla süren uzun savaşlar, Osmanlı maliyesi üzerine ek masraflar getirmişti. Osmanlı maliyesini olumsuz yönde etkileyen dâhilî sorunların yanı sıra 1580'li yıllardan başlayıp yarım asır kadar sürecek kıtalar arası altın ve gümüşün bol ve ucuz bir şekilde Osmanlı ülkesine gelmesi, enflasyonun yükselmesine neden olmuştu. ${ }^{85}$ Merkezî yönetim yaşanan malî buhranlardan kurtulmak için $1586-$ $1587^{86}$ tarihinde ilk defa büyük tağşişe ${ }^{87}$ karar vermişti. Paranın ayarının düşürülmesi Osmanlı tebaasının, alım gücünü olumsuz etkilemişti.

\footnotetext{
${ }^{77}$ Başbakanlık Devlet Arşivleri Genel Müdürlüğü Osmanlı Arşivi Daire Başkanlığı, 5 Numaralı Mühimme Defteri, s. 33.

${ }^{78}$ Başbakanlık Devlet Arşivleri Genel Müdürlüğü Osmanlı Arşivi Daire Başkanlığı, 5 Numaralı Mühimme Defteri, s. 40.

${ }^{79}$ Ahmed Refik, Onuncu Asr-1 Hicrî’ de İstanbul Hayat1 (1495-1591), Enderun Kitabevi, İstanbul, 1998, s. 102.

${ }^{80}$ Başbakanlık Devlet Arşivleri Genel Müdürlüğü Osmanlı Arşivi Daire Başkanlığı, 6 Numaralı Mühimme Defteri, s. 8.

${ }^{81}$ BOA MD 74, h. 269, s. 94.

${ }^{82}$ BOA MD 76, h. 127, s. 51.

${ }^{83}$ Başbakanlık Devlet Arşivleri Genel Müdürlüğü Osmanlı Arşivi Daire Başkanlığı, 5 Numaralı Mühimme Defteri, s. 176. Benzer hükümler için bakınız: BOA MD 51, h. 135, s. 59, Başbakanlık Devlet Arşivleri Genel Müdürlüğü Osmanlı Arşivi Daire Başkanlığı, 7 Numaralı Mühimme Defteri, s. 486

${ }^{84}$ Mustafa Akdağ, a.g.e., s. 271.

${ }^{85}$ Şevket Pamuk, Osmanlı Ekonomisi ve Kurumları, IV. Baskı, Türkiye İş Bankası Kültür Yayınları, Çeviren: Gökhan Aksay, İstanbul, 2013, s. 50.

${ }^{86}$ Ekrem Erdem, “Osmanlı Para Sistemi ve Tağşiş Politikası: Dönemsel Bir Analiz”, Bankacılar Dergisi, Sayı 56, 2006, s. 23.
} 
Osmanlı Devleti'nde XVI. yüzyılın ikinci yarısında savaş ekonomisinin uygulanması aynı zamanda kaçakçılık olaylarının artmasına sebep olmuştu. Şöyle ki "İyice azan enflasyon erzak kaçırmayı ve yaygın vurgunculuğu körükledi. Ülke içine gümüş akışının ve nüfus baskısının etkisiyle süren "fiyat devrimi”"ne savaş taleplerinin ve Büyük Kuraklık'la bağlantılı sikıntıların eklenmesi maliyetleri yukarı firlattı. Barkan 1489/1490 yılını taban alarak, temel gıda ürünlerinde akçe cinsinde fiyat endeksinin 1588/1589'da 365,52'ye yükseldiğini, Haçova Muharebesi'ne doğru 441,58'e sıçradı̆̆ını ve sadece bir yıl sonra aniden 532,07'ye tırmandığını hesaplar." ${ }^{88}$ Savaş ekonomisinin uygulandığı yıllarda doğal ve beşerî faktörlerden kaynaklanan enflasyondan daha fazla enflasyonun yaşanması, Osmanlı'da kaçakçılık olaylarının artarak devam etmesine yol açmıştı. Osmanlı Devleti bir yandan fiyatların artmaması için gayret sarf ederken diğer yandan da kaçakçılarla mücadele etmek zorunda kalmıştı. Artan emtia fiyatları karşısında maliyenin hesapları ile piyasa hesapları arasında fiyat farklarının yaşanması kaçakçılara firsatlar sunmaktaydı. Şöyle ki 1592 y1lında üzümün kantarı 50 ile 60 akçe arası olarak resmen belirlenmişken İzmit’te üzümün kantarı 120 akçeye satılmaktaydı. ${ }^{89}$

Osmanlı para birimi akçenin değer kaybetmesi, malî buhranların yaşanması ile Celâli isyanlarının oluşturduğu kırsaldan şehir merkezlerine yapılan göçler vs. gibi olaylar, Avrupa'ya hububat ve yasaklı malzemelerin satılmasında etkili olmuştu. ${ }^{90}$

\section{E) Merkezî Yönetimin Karaborsacılar ile Kaçakçılara Karşı Aldığı Tedbirler}

Merkezî yönetim, fiyat hareketlerini denetleyen narh sistemini hayata geçirmişti. Bu şekilde hem tebaanın enflasyonun üzerinde mal ya da ürün alması engellenmiş hem de tüccarın zarar etmesine mani olunmuştu. Para politikası ile denetim araçlarının yanı sıra emtia fiyatlarının artmasında manipülasyon yapanlara ağır cezalar verilmişti. Bu cezalar arasında para cezası başta olmak üzere hapis, ${ }^{91}$ teşhir, uyarı, dayak cezaları ile karaborsacının/muhtekirin malına el konulması ile tebaaya malının bedava dağıtılıp iflasa sürüklenmesine yol açan malî cezalar da bulunmaktaydı $1 .{ }^{92}$ Şayet karaborsacılar, devlet memuru ise sürgün cezasına çaptırılmaktaydılar. ${ }^{93}$ Böylece merkezî yönetimce, karaborsacılara adlî, malî cezalar verilerek mücadele edilmişti.

Yaptırımı ağır olan cezaların yanı sıra kanuni olarak da hububat stokçuluğunun önlenmesi için tüccarlara ahkâm-1 şerifeler verilmişti. Bu şekilde ellerinde belgesi olanların, hububat ticareti yapmasına izin verilerek kanuni önlemler alınmıştı. ${ }^{94}$ İdarî ve kanuni bazı tedbirlerin alınmasının yanı sıra tartı araç gereçlerine düzenlemeler de getirilerek haksızlıkların önü alınmak istenmişti. Şöyle ki kurutulmuş meyvelere uygulanan hacim üzerindeki fiyatlandırılmaya son verilmişti. Ayrıca İzmir'de kullanılan ağırlık birimi İstanbul'da kullanılan ağırlık birimine uyarlanmıştı. ${ }^{95} \mathrm{Bu}$ bağlamda Marmara kadısına gönderilen hüküm de Balya kazasında kullanılan kilenin ölçüsünün tam belirli olmayışından dolayı alış verişlerde tebaanın zarar gördüğü belirtilmiş. Bu hususta tebaa için Balya kazasında kullanılan kilenin mi yoksa İstanbul kilesinin mi kullanılmasının faydalı olacağı araştırılarak karar verilmesi emredilmişti. ${ }^{96}$

\footnotetext{
${ }^{87}$ Tağşiş: 1. Saf ve halis bir maddenin içerisine başka maddeler karıştırarak onun saflığını ve ayarını bozmak. 2. Osmanlı tarihinde paranın yani akçenin içerisindeki gümüş oranının düşürülmesi hadisesine tağşiş politikası denir (Pamuk, vd). Mehmet Ali Ünal, a.g.s., s. 658.

${ }^{88}$ Sam White, a.g.e., s. 204.

${ }^{89}$ Sam White, a.g.e., s. 205.

${ }^{90}$ Mustafa Akdağ, a.g.e., s. 43.

${ }^{91}$ Ziya Kazıc1, a.g.e., s. 92.

92 Zafer Karademir, a.g.e., s. 120-121.

${ }^{93}$ Başbakanlık Devlet Arşivleri Genel Müdürlüğü Osmanlı Arşivi Daire Başkanlığı, 6 Numaralı Mühimme Defteri, s. 226.

${ }^{94}$ Zafer Karademir, a.g.e., s. 124-125.

${ }^{95}$ Suratya Faroqh1, a.g.e., s. 101.

${ }^{96}$ BOA MD 12, h. 485, s. 505.
} 
Bu cezaların yanı sıra herhangi bir yerde yaşanan zahire kıtlığına karşı merkezî yönetim, başka idari birimlerinde (eyalet, sancak, kaza ve karyeler) toplanan zahireleri, kıtlık yaşanan yerlere naklederek tebaanın sıkıntı yaşamasını önlemeye çalışmışı. Ancak bölgesel nitelikli bu sunî tedbirler karaborsacılık ve kaçakçılığın önlenmesinde etkili olamamıştı. Buna rağmen karaborsacıların, kıtlık zamanında vurgun yapmalarına da mani olunmuştu. Şöyle ki Akkirman'da yaşanan zahire kıtlığına karşı Silistre, Varna, Balçık ile Samsun'da toplanan zahirenin, gemilerle Akkirman'a taşınması emredilmişti. ${ }^{97}$ Antalya kadısına gönderilen hüküm de ise Trablusşam vilayetinde yaşanan zahire kıtlığı sebebiyle Antalya ahalisinin ihtiyacından fazla olan zahiresinin, gelen gemilerle Trablusşam halkına satılması emredilmişti. ${ }^{98}$ Merkezî yönetimce alınan bölgesel nitelikli tedbirler az da olsa karaborsacılarla kaçakçıların yaşanan darlık/kıtlıkta istifade etmelerini engellemişti.

Zahire kıtlığına karşı alınan tedbirlerin aynı zamanda tebaanın et ihtiyacını karşılamaya yönelikte alındığ da bilinmektedir. Şöyle ki kasaba ve köylerde dişi koyunların kesilmemesine yönelik taşradaki yöneticilere hükümler gönderilmişti. ${ }^{99}$ Anaç koyunların kesilmesi önlenerek yaşanması muhtemel olan et sıkıntısının önü alınmak istenmişti. Başkentin et ihtiyacını karşılanması için taşradaki yöneticilere gönderilen hükümlerin genelinde, bıçağa yarayanların ${ }^{100}$ başkente gönderilmesi emredilmişti. Merkezî yönetimce hangi hayvanların kesilmek için başkente gönderilmesi hakkında bilgi verildiği görülmektedir. Burada belli bir plan dâhilinde hareket edilerek hem tebaanın et ihtiyacı karşılanmaya çalışılmış hem de koyunların rastgele kesilmesine müsaade edilmemişti.

Merkezî yönetim XVI. yüzyıl boyunca bir taraftan muhtekirlerle/karaborsacılarla uğraşırken diğer yanda kaçakçılığı önlemeye yönelik idarî tedbirler almıştı. Bu bağlamda gemi reislerine gönderilen hükümlerde belirlenen limanların haricinde demirlememeleri, ${ }^{101}$ ellerinde hüküm olmayan tüccarlara zahire satılmamas ${ }^{102}$ ile gemi kaptanlarına tereke taşımaları ve taşınan terekenin kaç müd olduğu ve nereye teslim edileceği vs. dair temessükler verilmişti. ${ }^{103}$ Ayrıca kaçakçılığın yapıldığı limanlara, Küffar gemilerinin yanaştırılmaması taşra yöneticilerine emredilmişti. ${ }^{104} \mathrm{Bu}$ bağlamda Gelibolu ve Rodoscuk kadılarına gönderilen hüküm de Mısır'da zahire getiren gemilerin taşıdıkları zahireyi limanlara yanaşarak sattıkları bu sebeple başkentte zahire kıtlığı yaşandığı belirtilip kaptanların zahire kaçakçıllı̆ı yapmamaları için gemilerin ambarlarının mühürlenmesi emredilmişti. ${ }^{105}$

Osmanlı Devleti'nin özellikle küffara yakın yerlerdeki yolların denetimi naibler ve yanındakilere yaptırılarak engellenmeye çalışılmıştı. Bu bağlamda Ohri beyi ile Ohri ile Istaruva kadılarına gönderilen hüküm de Küffara tereke ve meta' satılmaması gerektiği ve yollarda tereke satmak için gidenlerin, naib ve yanındakiler tarafından geri gönderilmesi gerektiği belirtilmişti. ${ }^{106}$

Taşradaki yöneticilere, kaçakçılarla mücadelede görevini suistimal edenlere ağır cezalar verileceğine dair pek çok hükümler gönderilmişti. Şöyle ki Gelibolı'da Hassa Emini'ne, kaçakçılarla mücadelede ihmalkâr davranılmaması gerektiği şayet herhangi bir şekilde ihmalinin

\footnotetext{
${ }^{97}$ Başbakanlık Devlet Arşivleri Genel Müdürlüğü Osmanlı Arşivi Daire Başkanlığı, 6 Numaralı Mühimme Defteri, s. 208.

${ }^{98}$ BOA MD 51, h. 213, s. 95.

${ }^{99}$ BOA MD 72, h. 340, s. 178.

100 BOA MD 12, h. 485, s. 927.

101 BOA MD 73, h. 980, s. 444.

${ }^{102}$ Başbakanlık Devlet Arşivleri Genel Müdürlüğü Osmanlı Arşivi Daire Başkanlığı, 5 Numaralı Mühimme Defteri, s. 95.

${ }^{103}$ BOA MD 71, h. 90, s. 44.

104 BOA MD 69, h. 119, s. 66-2.

105 BOA MD 71, h. 97, s. 47.

106 BOA MD 51, h. 104, s. 45.
} 
tespit edilmesi halinde ağır cezaya çaptırılacağı belirtilmişti. ${ }^{107}$ İznikmid ve Yalak-âbâd kadılarına gönderilen hüküm de kaçakçılıkla mücadelede herhangi bir zafiyet gösterilmesi halinde azl edilecekleri gibi çeşitli cezalara da çaptırılacakları belirtilmişti. ${ }^{108}$ Bunun gibi küffara kaçak olarak tereke satanlar hakkında "şer'le haklarında geline", ${ }^{109}$ siyaset oluna ${ }^{110}$ gibi hükümlerin bulunması, kaçakçılara ölüm cezası verilmesi gerektiği anlaşılmaktadır. Bazen de gönderilen hükümlerin son kısımlarında kaçakçılarla mücadelede daha etkin olunmasına yönelik "ihmâl ü müsâhele itmeyüp" ibarelerin bulunmaktayd1.

Ticarî öneme sahip limanlarda kaçakçılık yapılıp küffara tereke satılması durumunda o limanlarda bir daha tereke yüklenmeyeceğine dair kesin hükümler de bulunmaktaydı. Bu bağlamda İbrice Limanından, İstanbul'a gönderilmesi için yüklenen terekelerin küffara satılması üzerine bir daha kesinlikle bu limanda tereke taşımacılığının yapılmayacağı Keşan kadısına emredilmişti. ${ }^{111}$ Burada merkezî yönetimin, kaçakçılara karşı aldığı tedbirlerde ne kadar kararlı olduğu görülmektedir.

Zahire kaçakçılığının yanı sıra meyve kaçakçılığı da yapılmıştı. İzmir limanında kara üzüm, badem, incir gibi meyveler başkente gönderilmesi gerekirken geminin küffar tarafina hareket ettiğinin öğrenilmesi üzerine başkente taşıdığı meyvelerle getirilmesi İzmir kadısı ile Kocakaleli dizdarına emredilmişti. ${ }^{112}$ Böylece kaçırılan ve ihtiyaç duyulan meyvelerin tekrar getirilmesi için kolluk marifetiyle tedbir alınmıştı.

Merkezî yönetim bir taraftan çeşitli idarî, malî ve cezaî tedbirlerle karaborsacıllı̆̆ ve kaçakçıllğı önlemeye çalışırken diğer taraftan da pazar ekonomisini kontrol etmeyi ihmal etmemişti. Şöyle ki Erzurum defterdarına gönderilen hüküm de Erzurum'da zahire kıtlığının yaşanıp yaşanmadığı, arpa ve buğdayın kilesinin kaç akçe olduğu sorularak pazar ekonomisi hakkında bilgi alıp yerinde kontrolü sağlayarak emtia fiyatlarının aşırı pahalanmaması için teftiş ettirmişti. ${ }^{113}$

Merkezî yönetim iklimsel koşullar ile haşaratın tarım alanlarına vermiş olduğu zararlardan ${ }^{114}$ dolayı tebaanın gündelik yaşamını idame ettirmede herhangi bir sorunla karşılaşmaması için kıtlık ya da darlı̆̆ın yaşandığı yerlerde aynî olarak alınan vergileri af etmişti. Böylece yaşanan kıtlık ya da darlıkta karaborsacıların tebaayı istismar etmelerinin önü de alınmış olmaktaydı. Bu bağlamda Peçin kadısı yıllık İstanbul kilesiyle üç yüz kile buğdayı Rodos'a göndermeleri gerekirken yüz on kile buğday gönderdiklerini arz etmiş̧ti. Geri kalan kısmın ise yaşanan kuraklık ve çekirge istilası nedeniyle gönderemediklerini ve tebaanın mağdur olmaması için af edilmesi şeklindeki arzına binaen tebaanın buğday vermeye kudretlerinin olmaması halinde affına karar verildiği kadıya gönderilen hükümle belirtilmişti. ${ }^{115}$

Osmanlı Devleti'nin kudretli olduğu Kanunî döneminde karaborsacılık ve kaçakçılık suçları fazla yaşanmamıştı. Ancak II. Selim ve III. Murat ile III. Mehmet dönemlerinde karaborsacılık ve kaçakçılıkla mücadelede edilmesi için taşradaki yöneticilere çok miktarda tezkereler ${ }^{116}$

\footnotetext{
${ }^{107}$ Başbakanlık Devlet Arşivleri Genel Müdürlüğü Osmanlı Arşivi Daire Başkanlığı, 6 Numaralı Mühimme Defteri, s. 24.

${ }^{108}$ Başbakanlık Devlet Arşivleri Genel Müdürlüğü Osmanlı Arşivi Daire Başkanlığı, 6 Numaralı Mühimme Defteri, s. 45.

${ }^{109}$ BOA MD 73, h. 985 , s. 447.

${ }_{110}$ BOA MD 12, h. 525, s. 1022.

${ }^{111}$ Başbakanlık Devlet Arşivleri Genel Müdürlüğü Osmanlı Arşivi Daire Başkanlığı, 6 Numaralı Mühimme Defteri, s. 28.

112 BOA MD 72, h. 388, s. 202.

113 BOA MD 32, h. 445, s. 240.

${ }^{114}$ Savaș Yılmaz, a.g.m., s. 756.

115 BOA MD 12, h. 983, s. 513

${ }^{116}$ Sam White, a.g.e., s. 203.
} 
gönderilmişti. Devlet otoritesinin sarsılmaya başladığı dönemlerde, karaborsacılık ve kaçakçılık suçları artmıştı.

\section{SONUÇ}

XVI. yüzyılda Osmanlı Devleti'nin, ülke genelinde yaşanan kıtlıkların ana sebebi olarak karaborsacılık ile kaçakçılığa bağlı hububat, meyve, et gibi küffara satılması yasak olan ürünlerin satılmasını görmesi, tarım ve köylü bileşkesinde meydana gelen değişimlerin farkında olmadığını göstermektedir. XVI. yüzyılda merkezî yönetim, tarım alanlarının ıslahına yönelik ciddi çalışmalar yapamadığ 1 gibi köylülerin tarım arazilerinde birim alanda elde edecekleri, yıllık ürün miktarını artırıcı çalışmalarda da bulunamamıştı. Yani tarım ve tarıma bağlı iş kolu olan hayvancılıkta yenilikçiliğin öncüsü olamamış, doğma öğretilerle kanunlar muvacehesinde hareket etmişti. Bu bağlamda ülke genelinde yaşanan hububat başta olmak üzere bazı emtia yokluğunu/kıtllğını, karaborsacılık ya da kaçakçılık olayları ile ilişkilendirmişti. Bu bağlamda tarım alanlarının terk edilmesi, kırsal bölgelerin güvenliğinin sağlanamaması, Osmanlı kentlerinde hububat ile et başta olmak üzere temel gıda maddelerinin fiyatının aşırı artmasında etkili olmuştu. Merkezî yönetim tarım ve hayvancılık politikasında köklü yeniliklere gidilemediği gibi mevcut durumun sürmesi için gayret etmişti. Bu nedenle kanun ve kolluk marifetiyle yaşanan kıtlık/darlıklara son vermeyi amaçlayan merkezî yönetim, devlet memurlarının dahi karaborsacılık ve kaçakçılık yapmasına mani olamamıştı.

XVI. yüzyıl boyunca devam eden kaçakçılık olayları ise Osmanlı maliyesi üzerine ağır baskılar oluşturmuştu. $\mathrm{Bu}$ dönemde yapılan karaborsacılık ile kaçakçılık olayları Osmanlı maliyesinin vergi kaybına sebep olmuştu Osmanlı Devleti bütçe açıklarını kapatmak için çareyi yeni ek vergiler koymakta bulmuştu. Bu durum ise her hâlükârda tebaanın zarar görmesine neden olmuştu. Şöyle ki XVI. yüzyılda yaşanan kıtlık/darlıklardan dolayı emtia fiyatları artmış, tebaa gündelik ihtiyaçlarını karşılamakta zorluklarla karşılaşmıştı.

Az veya kıt olan ülke içerisindeki ürünlerin fahiş fiyatlarla satılması, karaborsacılığı cazip hale getirmişti. Kaçakçılığı cazip hale getiren sebepler arasında kaçakçıların sattıkları ürünleri ülke içerisinde sattıklarından daha pahalıya yabancılara satmaları ile satılan ürünün vergisini devlete vermemeleri gösterilebilir. Bu bağlamda kaçakçılıkla beraber devletten vergi de kaçırılmış olmaktaydı. Devlete verilmesi gereken belli oranlardaki vergiler yani paralar kaçakçıda kalmaktaydı. Bu bağlamda karaborsacılık ile kaçakçılık, tebaayı mağdur ettiği gibi devletin doğrudan gelir kalemleri arasında yer alan vergilerde de bir azalmaya yol açmıştı. Böylece devletin ihracatını yasakladığı emtianın satılması, iç pazarlarda bir daralma ile kıtlı̆̆ da beraberinde getirmişti.

Osmanlı Devleti'nde özellikle XVI. yüzyılın ilk yarısında karaborsacılık ile kaçakçılık suçları sınırlı sayıda iken bu yüzyılın ikinci yarısında yoğunluk kazanmıştı. Bu durumun yaşanmasında; timar sisteminin bozulmasıyla beraber reâyâ (üretici) ile doğal kaynaklar (tarım arazileri, bahçe vs.) arasında ki işlerliğin bozulması buna bağlı olarak kır alanlarından kentlere göçlerin yaşanması etkili olmuştu. Bu durumun sonucu olarak köyler viraneye dönmüş, şehirlerin ve kazaların nüfusu aşırı artmış, temel gıda maddelerinin sağlanmasında zorluklar yaşanmıştı.

Osmanlı Devleti'nin bu yüzyıl içerisinde kronikleşmiş sorunları arasında yer alan tarım alanlarının 1slah edilemeyişi, köylülerin çağın gereklerine göre üretim araçlarının modernizasyonunu yapamayışı da başka bir neden olarak belirmişti. Üretimin sınırlı olması ve tüketimin kontrol edilemeyişi, Celâli isyanlarının kır yerleşkelerinde daha etkili olması karşısında merkezî yönetimin kır yerleşkelerinin güvenliğini sağlamada yetersiz kalması, kentlere yapılan göçün durdurulup kır hayatını daha cazip hale getirici tedbirlerin alınamaması üretimi düşürmüştü. Buna bağlı olarak arz-talep dengesi bozulmuş ve üretimin talebi karşılayamaması nedeniyle emtia fiyatları artmıştı. Enflasyona bağlı olarak tebaanın da alım gücü düşmüştü. Tüccar ve esnaflar ise 
aşırı kâr etmek istedikleri için XVI. yüzyılın özellikle ikinci yarısında Osmanlı Devleti’nde, karaborsacılık olaylarında bir artış yaşanmıştı.

\section{KAYNAKÇA}

Arşiv Belgeleri

BOA MD 12: 505, 513, 927, 1022.

BOA MD 23: 193 .

BOA, MD 27: 350, 333, 334, 363, 795, 796.

BOA, MD 32: 240.

BOA, MD 47: 36, 203, 208.

BOA, MD 48: 62, 92.

BOA, MD 49: 113 .

BOA, MD 51: 29, 45, 59, 95.

BOA, MD 53: 160 .

BOA, MD 69: 19-2, 36-1, 44-1, 66-2.

BOA, MD 70: 6, 7, 32, 376.

BOA, MD 71: $31,42,47$

BOA, MD 72: 178, 202.

BOA, MD 73: 444, 447, 454, 979.

BOA, MD 74: 94.

BOA, MD 76: 51.

\section{Kitap ve Makaleler}

ACIPINAR, Mikail, Osmanlı İmparatorluğu Ve Floransa Akdeniz'de Diplomasi, Ticaret Ve Korsanlık 1453 - 1599, Türk Tarih Kurumu Yayınları, Ankara, 2016.

AKDAĞ, Mustafa, Türk Halkının Dirlik Ve Düzenlik Kavgası, II. Baskı, Yapı Kredi Yayınları, İstanbul, 2013.

ALBAYRAK, Sadık, Budin Kânunnâmesi ve Osmanlı Toprak Meselesi, Tercüman Yayınları, İstanbul, 1973.

ÂLI, Gelibolulu Mustafa, Siyaset Sanatı Nushatü's -Selâtîn, Hazırlayan: Faris Çerçi, Büyüyenay Yayınları, İstanbul, 2015.

BARKAN, Ömer Lütfi, XV. Ve XVI ıncı Asırlarda Osmanlı İmparatorluğunda Ziraî Ekonominin Hukukî Ve Malî Esasları, Yayına Hazırlayan: : Hüseyin Özdeğer, İstanbul, 2001.

BARKEY, Karen, Eşkıyalar ve Devlet Osmanlı Tarzı Devlet Merkezîleşmesi, Çev.: Zeynep Altıo, (II. Baskı), Tarih Vakfı Yurt Yayınları, İstanbul, 2011.

Başbakanlık Devlet Arşivleri Genel Müdürlüğü Osmanlı Arşivi Daire Başkanlığı, 5 Numaralı Mühimme Defteri (973/1565-1566) Özet Transkripsiyon, Ankara, 1994

Başbakanlık Devlet Arşivleri Genel Müdürlüğü Osmanlı Arşivi Daire Başkanlığı, 6 Numaralı Mühimme Defteri (972 / 1564-1565), Özet-Transkripsiyon, Ankara, 1995.

Başbakanlık Devlet Arşivleri Genel Müdürlüğü Osmanlı Arşivi Daire Başkanlığı, 7 Numaralı Mühimme Defteri, (975-976 / 1567-1569), Özet - Transkripsiyon, Ankara, 1998. 


\section{F.Ü. Sosyal Bilimler Dergisi 2020-30/2}

CEZAR, Mustafa, Osmanlı Tarihinde Levendler, Çelikcilt Matbaası, İstanbul, 1965.

FAROQHI, Suraiya, Osmanlı'da Kentler Ve Kentliler, Çev.: Neyyir Berktay, V. Baskı, tarih Vakfı Yurt yayınları, İstanbul, 2011.

DEMIRCI, Süleyman, ARSLAN, Hasan, Osmanlı Türkiyesi’nde Eşkıya, Devlet ve Siyaset, Yalın Yayıncılık, İstanbul, 2012.

GENÇ, Mehmet, Osmanlı İmparatorluğu'nda Devlet Ve Ekonomi, XI. Baskı, Ötüken Neşriyat, İstanbul, 2014.

İSLAMOĞLU, Huricihan, Osmanlı İmparatorluğu'nda Devlet ve Köylü, II. Baskı İletişim Yayınları, İstanbul, 2010.

KAZICI, Ziya, Osmanlı'da Yerel Yönetim (İhtisab Müessesesi), Bilgi Yayınevi, İstanbul, 2006.

KOÇ, Mehmet, Osmanlı Hukukunda Ta'zir Suç ve Cezalar, Aybil Yayınları, Konya, 2017.

KÜTÜKOĞLU, Mübahat, XVI. Asırda Çeşme Kazasının Sosyal ve İktisâdî Yapısı, Türk Tarih Kurumu, Ankara, 2010.

ÖZ, Mehmet, XV-XVI. Yüzyıllarda Canik Sancağı, Türk Tarih Kurumu, Ankara, 1999.

PAKALIN, Mehmet, Zeki, Osmanlı Tarih Deyimleri Ve Terimleri Sözlüğü, Cilt: II, Milli Eğitim Yayınları, İstanbul, 1946.

PAMUK, Şevket, Osmanlı İmparatorluğu'nda Paranın Tarihi, Türkiye İş Bankası Kültür Yayınları, İstanbul, 2017.

PAMUK, Şevket, Osmanlı Ekonomisi ve Kurumları, Türkiye İş Bankası Kültür Yayınları, İstanbul, 2013.

REFiK, Ahmet, Onuncu Asr-1 Hicrî’de İstanbul Hayatı (1495 - 1591), Enderun Kitabevi, İstanbul, 1998.

SÂMİ, Şemseddin, Kâmûs-1 Türkî, Çağrı Yayınları, İstanbul, 1995.

SAYAR, Ahmet, Güner, Osmanlı İktisat Düşüncesinin Çağdaşlaşması, II. Baskı, Ötüken Yayınevi, İstanbul, 2000.

UZUNÇARŞILI, İsmail, Hakkı, Osmanlı Tarihi, Cilt: II, Türk Tarih Kurumu Yayınları, Ankara, 2011.

ÜNAL, Mehmet, Ali, Paradigma Osmanlı tarih Sözlüğü, Paradigma Yayınları, İstanbul, 2010.

ÜNAL, Mehmet, Ali, Osmanlı Sosyal ve Ekonomik Tarihi, Paradigma Yayınları, İstanbul, 2012.

KARADEMİR, Zafer, İmparatorluğun Açlıkla İmtihanı Osmanlı Toplumunda Kıtlıklar (1560-1660), Kitap Yayınevi, II. Bask1, İstanbul, 2017.

YILMAZ, Savaş, "XVI. Yüzyılın İkinci Yarısında Üretimden Pazara Osmanlı Köylüsünün Karşılaştı̆ı Yapısal Sorunlar ve Bu Sorunlara Karşı Merkezî Yönetimin Aldığı Tedbirler", VakanüvisUluslararası Tarih Araştırmaları Dergisi/International Journal Of Hıstorical Researches, Sayı: 4, 2019, ss. 746-778.

WHITE, Sam, Osmanlı'da İsyan İklimi Erken Modern Dönemde Celali İsyanları, Çev.: Nureddin Elhüseyni, Alfa Yayınları, İstanbul, 2013. 